\title{
Age-Associated Changes in Antioxidants and Redox Proteins of Rat Heart
}

\author{
P. KAPLÁN ${ }^{1,2}$, Z. TATARKOVÁ ${ }^{1}$, L. LICHARDUSOVÁ ${ }^{1}$, M. KMEŤOVÁ SIVOŇOVÁ ${ }^{1}$, \\ A. TOMAŠCOVÁ ${ }^{1}$, P. RAČAY ${ }^{1,2}$, J. LEHOTSKÝ ${ }^{1,2}$ \\ ${ }^{1}$ Department of Medical Biochemistry, Comenius University in Bratislava, Jessenius Faculty of \\ Medicine, Martin, Slovak Republic, ${ }^{2}$ Biomedical Center Martin, Comenius University in Bratislava, \\ Jessenius Faculty of Medicine, Martin, Slovak Republic
}

Received March 22, 2019

Accepted July 19, 2019

Epub Ahead of Print October 25, 2019

\section{Summary}

Oxidative stress and decline in cellular redox regulation have been hypothesized to play a key role in cardiovascular aging; however, data on antioxidant and redox regulating systems in the aging heart are controversial. The aim of the present study was to examine the effect of aging on critical antioxidant enzymes and two major redox-regulatory systems glutathione (GSH) and thioredoxin (Trx) system in hearts from adult (6-month-old), old (15-month-old), and senescent (26-monthold) rats. Aging was associated with a non-uniform array of changes, including decline in contents of reduced GSH and total mercaptans in the senescent heart. The activities of Mn-superoxide dismutase (SOD2), glutathione peroxidase (GPx), glutathione reductase (GR), and thioredoxin reductase (TrxR) exhibited an age-related decline, whereas catalase was unchanged and $\mathrm{Cu}, \mathrm{Zn}$-superoxide dismutase (SOD1) displayed only slight decrease in old heart and was unchanged in the senescent heart. GR, Trx, and peroxiredoxin levels were significantly reduced in old and/or senescent hearts, indicating a diminished expression of these proteins. In contrast, SOD2 level was unchanged in the old heart and was slightly elevated in the senescent heart. Decline in GPx activity was accompanied by a loss of GPx level only in old rats, the level in senescent heart was unchanged. These results indicate age-related posttranslational protein modification of SOD2 and GPx. In summary, our data suggest that changes are more pronounced in senescent than in old rat hearts and support the view that aging is associated with disturbed redox balance that could alter cellular signaling and regulation.

\section{Key words}

Heart • Aging • Antioxidant enzymes • GSH redox system • Thioredoxin redox system

\section{Corresponding author}

P. Kaplan, Department of Medical Biochemistry and BioMed, Comenius University in Bratislava, Jessenius Faculty of Medicine, Mala Hora 4D, 03601 Martin, Slovak Republic. Email: kaplan@jfmed.uniba.sk

\section{Introduction}

Aging is characterized by alterations in cardiac structure and significant decline in cardiac pump function and contractile reserve. Among theories of aging the free radical theory has drawn a widespread attention. Although the mechanisms of aging are not fully understood a chronic oxidative stress and gradual accumulation of cellular oxidative damage are thought to be the major factors. Reactive oxygen species (ROS) and other oxidants are constantly generated throughout the lifespan, even immediately after birth (Wilhelm et al. 2015). It is well established that mitochondria are one of the major sources of cellular ROS (Cedikova et al. 2016). They are generated mainly as by-products of oxidative metabolism and may play critical role mitochondrial damage during aging. Several studies including ours have shown that aging is associated with decline in activities of mitochondrial enzymes (Kumaran et al. 2005, Tatarková et al. 2011), increased ROS formation (Bejma et al. 2000, Petrosilo et al. 2009, Kuka et al. 2011) and accumulation of lipid peroxidation products and oxidatively modified proteins (Preston et al. 2008, Choksi and Papaconstantinou 2008, Tatarková et al. 2011). Oxidative 
stress, an imbalance between oxidants and antioxidants may also result from disturbances in the antioxidant defense system with aging. The antioxidant system includes enzymes superoxide dismutases (Mn-SOD, $\mathrm{Cu}, \mathrm{Zn}-\mathrm{SOD})$, glutathione peroxidase (GPx), glutathione reductase (GR), catalase, thioredoxin (Trx), thioredoxin reductase (TrxR), and peroxiredoxin (Prx) and nonenzymatic antioxidants, such as glutathione (GSH) and protein thiols. The data on the status of antioxidant defense systems in the aging heart are controversial (Judge et al. 2005, Tian et al. 1998, Lennon-Edwards et al. 2015) or are lacking. Moreover, several studies on transgenic mice have shown that alterations in the expression of antioxidant genes results in altered accumulation of oxidative damage, but have little effect on animal life span (Van Remmen et al. 2003, Salmon et al. 2010). Based on these findings an alternative hypothesis of aging was formulated suggesting progressive overoxidation of protein thiols resulting in disturbance in redox signaling mechanisms (Sohal and Orr 2012). Growing evidence indicates that besides their adverse effects ROS play an important role in cellular signaling pathways. Relatively mild oxidant hydrogen peroxide $\left(\mathrm{H}_{2} \mathrm{O}_{2}\right)$, which is produced from superoxide by $\mathrm{Mn}-\mathrm{SOD}$, can react with specific cysteine residues in proteins. Oxidation of cysteines to disulfides may result in structural and/or functional changes of proteins, such as enzymes, ion transporters, receptors, transcription factors, and structural proteins. Protein changes are reversible since disulfide bonds can be reduced to thiols by glutathione system and thioredoxin system. These disulfide reductases play a key role in regulating redox homeostasis and deterioration of their function might be involved in disruption of cellular redox regulation. There is increasing evidence that protein thiol oxidation is involved in cardiovascular diseases and aging (Mailloux et al. 2014), however, less is known about effect of aging on expression and function of cellular redox systems. Published studies show conflicting results, decreased, increased or unaltered contents/activities were reported to be found in the aging heart (Tian et al. 1998, Shinohara et al. 2000, Meng et al. 2007, Judge et al. 2005, Bulvik et al. 2009, Picard et al. 2012).

In this context, the aim of the present study was to examine the effect of aging on major antioxidant enzymes and disulfide reductases. For this purpose, we determined enzyme expressions and activities in homogenates prepared from hearts of 6-, 15-, and 26-month-old rats.

\section{Methods}

Animals

Male Wistar rats were obtained from Institute of Experimental Pharmacology, Slovak Academy of Sciences, Dobra Voda, Slovak Republic. Animals were divided into three groups (5 rats per group) according to age, as adult (6-month-old), old (15-month-old) and senescent (26-month-old). They were housed in an air-conditioned and light-controlled room as described previously (Kaplan et al. 2007). The experimental protocols were conducted in accordance with the European Community guidelines (Directive 2010/63/EU) and were approved by the Ethical Committee of the Jessenius Faculty of Medicine.

Preparation of heart homogenate and isolation of mitochondrial and cytosolic fractions

Rats were sacrificed by decapitation after halothane anesthetization. The hearts were removed and immediately washed with physiological solution and stored at $-80{ }^{\circ} \mathrm{C}$. Frozen powdered tissue of the whole heart was thawed in 10 volumes of ice-cold homogenization buffer $\left(30 \mathrm{mM} \mathrm{KH_{2 }} \mathrm{PO}_{4}, 5 \mathrm{mM}\right.$ EDTA, $0.3 \mathrm{M}$ sucrose, $\mathrm{pH} 7.0$ ) with $0.3 \mathrm{mM}$ phenylmethylsulfonyl fluoride and homogenized for five $25 \mathrm{~s}$ periods with a Teflon pestle in Potter-Elvehjem homogenizer.

Mitochondria were isolated from homogenates by differential centrifugation as previously described (Babušíková et al. 2004). Homogenates were filtered through one layer of cheesecloth and centrifuged at $1000 \times \mathrm{g}$ for $10 \mathrm{~min}$ at $4{ }^{\circ} \mathrm{C}$. The supernatant fractions were collected and further centrifuged at $18,000 \times \mathrm{g}$ for $35 \mathrm{~min}$. Mitochondrial pellets were resuspended in buffer containing $30 \mathrm{mmol} / \mathrm{l}$ imidazole, $60 \mathrm{mmol} / 1 \mathrm{KCl}$, $2 \mathrm{mmol} / 1 \mathrm{MgCl}_{2}$ (pH 7.0), and stored in aliquots at $-80^{\circ} \mathrm{C}$ until use.

For isolation of cytosolic fractions, the aliquots of heart homogenates were centrifuged at $3000 \times \mathrm{g}$ for $10 \mathrm{~min}$. The supernatant fractions were further centrifuged at $100,000 \times \mathrm{g}$ for $65 \mathrm{~min}$ and resulting supernatants were collected and stored at $-80{ }^{\circ} \mathrm{C}$ until use.

Determination of reduced glutathione and total mercaptans

Concentration of reduced glutathione (GSH) and total mercaptans (RSH) were determined using Glutathione assay kit according to manufacturer's instructions (Calbiochem, San Diego, USA). Briefly, 
$20 \mu \mathrm{l}$ of heart homogenates were diluted in phosphate buffer and mixed with solution of chromogenic reagent in $\mathrm{HCl}$. Chromophoric thione, produced after alkalization of solution with $\mathrm{NaOH}$, was determined spectrophotometrically at $400 \mathrm{~nm}$ after $10 \mathrm{~min}$ incubation in dark at room temperature. Total RSH were measured at $356 \mathrm{~nm}$ in the absence of $\mathrm{NaOH}$. GSH and $\mathrm{RSH}$ were quantified using prepared standard curve and the results are expressed as $\mu \mathrm{mol} / \mathrm{mg}$ protein.

\section{Determination of enzyme activities}

$\mathrm{Cu}, \mathrm{Zn}-\mathrm{SOD}$ (SOD1) and Mn-SOD (SOD2) activities were measured in cytosolic and mitochondrial fraction, respectively, by monitoring the inhibition of nitroblue tetrazolium (NBT) reduction by superoxide radical generated in xanthine oxidase reaction (Gonzales et al. 1984). The reaction mixture consisted of $50 \mathrm{mM}$ phosphate buffer ( $\mathrm{pH} 7.8$ ), $0.1 \mathrm{mM}$ EDTA, $0.025 \mathrm{mM}$ NBT, and $0.1 \mathrm{mM}$ xanthine. Formation of formazan due to NBT reduction was followed spectrophotometrically at $565 \mathrm{~nm}$ against control containing reaction mixture without sample. SOD activity was expressed as units that represent amount of enzyme causing $50 \%$ inhibition of NBT reduction.

Catalase activity was determined using Catalase assay kit according to manufacturer's instructions (Calbiochem, San Diego, USA). The method is based on the formation of formaldehyde from methanol in reaction catalyzed by catalase in the presence of $\mathrm{H}_{2} \mathrm{O}_{2}$. Briefly, heart homogenates were incubated in medium containing $100 \mathrm{mM}$ phosphate buffer, $\mathrm{pH} 7.0$ and methanol and reaction was started with $8.82 \mathrm{mM} \mathrm{H}_{2} \mathrm{O}_{2}$. The enzyme activity was measured by monitoring absorbance change at $540 \mathrm{~nm}$ due to formation of heterocycle of formaldehyde with a chromogen Purpald.

Glutathione reductase activity was determined using GR activity assay kit according to manufacturer's instructions (Sigma-Aldrich, St. Louis, USA). Method is based on the reduction of oxidized glutathione (GSSG) by NADPH catalyzed by GR. Samples of heart homogenates were incubated with $43 \mathrm{mM}$ phosphate buffer, $\mathrm{pH} 7.5,0.43 \mathrm{mM}$ EDTA, and $1 \mathrm{mM}$ GSSG and the reaction was started with $0.1 \mathrm{mM}$ NADPH. The rate was measured by monitoring absorbance decrease at $340 \mathrm{~nm}$.

Activity of GPx was measured by Glutathione peroxidase cellular activity assay kit according to manufacturer's instructions (Sigma-Aldrich, St. Louis, USA). Method is based on recycling of GSSG back to
GSH utilizing GR and NADPH. Homogenates were diluted in the assay solution containing $50 \mathrm{mM}$ Tris- $\mathrm{HCl}$, pH 8.0, 0.5 mM EDTA, 0.25 mM NADPH, $2.1 \mathrm{mM}$ reduced glutathione, and $0.5 \mathrm{unit} / \mathrm{ml}$ glutathione reductase. The reaction was started by adding $300 \mathrm{mM}$ $t$-Bu-OOH and the rate was measured by monitoring absorbance decrease at $340 \mathrm{~nm}$.

TrxR activity was determined using Thioredoxin reductase colorimetric assay kit according to manufacturer's instructions (Cayman, Ann Arbor, USA). The method is based on reduction of DTNB with NADPH in the absence and in the presence of aurothiomalate, a specific inhibitor of TrxR. Homogenates were incubated in the assay solution containing $50 \mathrm{mM}$ phosphate buffer, $\mathrm{pH} 7.0,1 \mathrm{mM}$ EDTA, and $0.2 \mathrm{mg} / \mathrm{ml} \mathrm{BSA} \mathrm{with} \mathrm{or} \mathrm{without} 20 \mu \mathrm{M}$ aurothiomalate. The reaction was initiated by adding DTNB and NADPH and the rate was measured by monitoring absorbance decrease at $405 \mathrm{~nm}$.

\section{Western blot analysis}

Cardiac proteins were separated by $10 \%$ SDSPAGE using a Mini-Protean electrophoresis cell (BioRad Laboratories, Hercules, USA) and then transferred into Immobilon-P transfer membranes (Millipore, Bedford, USA) using Mini Trans-Blot cell (BioRad Laboratories). Western blots were dried overnight and incubated in Trisbuffered saline $(20 \mathrm{mM}$ Tris/ $\mathrm{HCl}$ and $0.05 \%$ Tween-20) containing $5 \%$ non-fat dry milk. The blots were then incubated with following antibodies: anti-SOD1 sheep polyclonal antibody (Calbiochem, San Diego, USA) (1:1000) for 2h, anti-SOD2 (A2) mouse monoclonal antibody (Santa Cruz Biotechnology, Dallas, USA) (1:500) for $1 \mathrm{~h}$, anti-catalase goat polyclonal antibody (Santa Cruz Biotechnology, Dallas, USA) (1:500) for 1h, anti-glutathione reductase rabbit polyclonal antibody (Abcam, Cambridge, UK) (1:1000) $1 \mathrm{~h}$, anti-glutathione peroxidase 1 rabbit polyclonal antibody (Abcam, Cambridge, UK) (1:1000) $1 \mathrm{~h}$, anti-peroxiredoxin 2 rabbit monoclonal antibody (Abcam, Cambridge, UK) (1:1000) overnight, and anti-thioredoxin rabbit polyclonal antibody (Abcam, Cambridge, UK) (1:1000) overnight. After removal of the primary antibody the blots were incubated $1 \mathrm{~h}$ with appropriate secondary antibody. Chemi-fluorescent signal was detected on Chemidoc XRS (BioRad Laboratories) and the bands were integrated using GeneTools software (SynGene, India). 
Table 1. Effect of aging on body weight, heart weight and heart-to-body weight ratio

\begin{tabular}{lccc}
\hline & Body weight $(\mathbf{g})$ & Heart weight $(\mathbf{g})$ & Heart/body weight (mg/g) \\
\hline 6 months old & $408 \pm 7$ & $1.56 \pm 0.08$ & $3.81 \pm 0.18$ \\
15 months old & $475 \pm 26^{*}$ & $1.51 \pm 0.04$ & $3.20 \pm 0.16$ \\
26 months old & $499 \pm 13^{* * *}$ & $1.71 \pm 0.05$ & $3.43 \pm 0.11$ \\
\hline
\end{tabular}

Values are expressed as means \pm SEM of 5 experiments. ${ }^{*} p<0.05,{ }^{* * *} p<0.001$; significantly different as compared to 6 -months old rats.
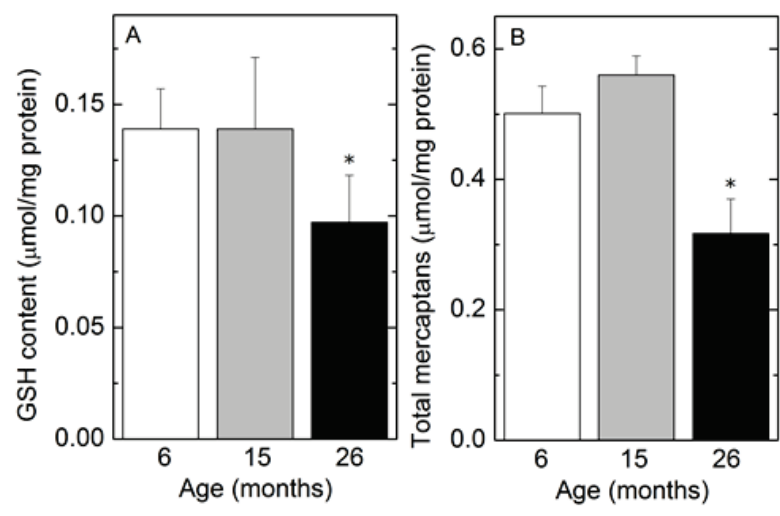

Fig. 1. Effect of aging on the contents of reduced glutathione, GSH (A) and total mercaptans (B). Values are given as mean \pm SEM of 5 experiments. $* \mathrm{p}<0.05$; significantly different as compared to 6-month-old rats.
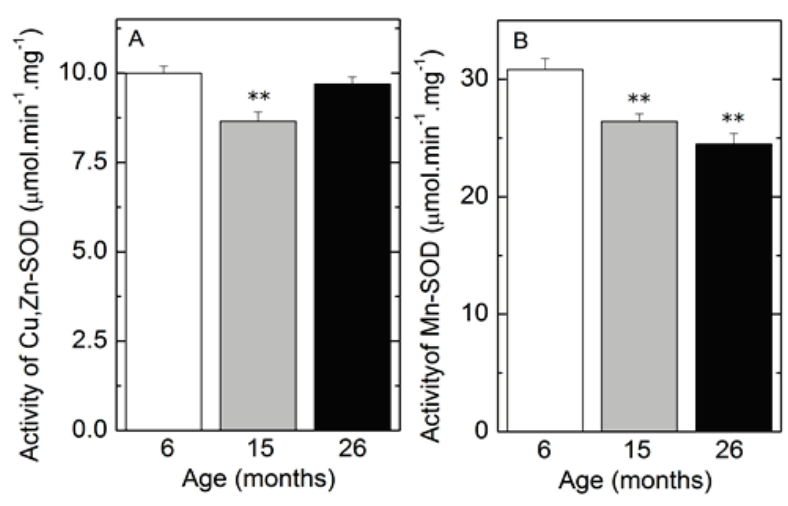

Fig. 2. Effect of aging on enzyme activities of $\mathrm{Cu}, \mathrm{Zn}$-superoxide dismutase, Cu,Zn-SOD (A) and Mn-superoxide dismutase, $\mathrm{Mn}-\mathrm{SOD}$ (B). Values are given as mean \pm SEM of 5 experiments. $* * p<0.01$; significantly different as compared to 6 -months-old rats.

\section{Results}

Body weights of the 15- and 26-month old rats were significantly higher than that of 6-month old rats (Table 1).

However, there were no significant differences in the heart weights and heart-to-body weight ratios among the age groups, indicating absence of cardiac hypertrophy.
The levels of reduced GSH and total mercaptans (RSH) were determined in the heart homogenates (Fig. 1). There was no difference in the levels of reduced GSH between control adult rats and 15-month-old rats, however, the level in senescent 26-month-old rats decreased significantly to $70 \pm 15 \%$ of control $(p<0.01)$. Also RSH was significantly altered only in hearts of senescent rats (Fig. 1B), the level decreased to $63 \pm 11 \%$ of control $(\mathrm{p}<0.01)$.

Activity of $\mathrm{Cu}, \mathrm{Zn}$-superoxide dismutase (SOD1) displayed only slight but significant decrease in old heart and was unchanged in the senescent heart (Fig. 2A). The SOD1 protein content did not show any significant age-dependent alteration (Fig. 4A). Unlike Cu,Zn-SOD the Mn-SOD (SOD2) activity decreased significantly in both aged groups (Fig. 2B) although level of SOD2 protein was unchanged (15-mo-old) or slightly elevated (26-mo-old) (Fig. 4B). Figures 3A and 4C show that catalase activity and content were slightly, but not significantly reduced in both aged groups. Figure 3B shows that GPx activity decreased significantly in both aged groups although GPx expression was reduced only in 15-month-old rats (Fig. 5A).

The activities and contents of GR were found to be significantly decreased in both aged groups (Figs. 3C and 5B). GR content decreased to $78 \pm 2 \%(\mathrm{p}<0.001)$ in old rats and to $62 \pm 2 \%(\mathrm{p}<0.001)$ in senescent rats. GR activity was reduced to $88 \pm 1 \%(\mathrm{p}<0.001)$ and $80 \pm 1 \%(\mathrm{p}<0.001)$ in old and senescent rats, respectively. Data presented in Fig. 3D show that thioredoxin reductase activity was similarly reduced in old $(78 \pm 1 \%$ of control, $\mathrm{p}<0.05)$ and senescent rat hearts $(75 \pm 7 \%$ of control, $\mathrm{p}<0.01)$. Moreover, significant decrease in the content of thioredoxin (Fig. 5C) was observed in both aged groups (to $38 \pm 4 \%, \mathrm{p}<0.01$ and $41 \pm 6 \%, \mathrm{p}<0.01$ when compared with control group, for old and senescent rats, respectively). On the other hand, the content of peroxiredoxin 2 was unchanged in old rats (Fig. 5D) but was significantly reduced in senescent rats $(65 \pm 1 \%$ of control, $\mathrm{p}<0.001)$. 

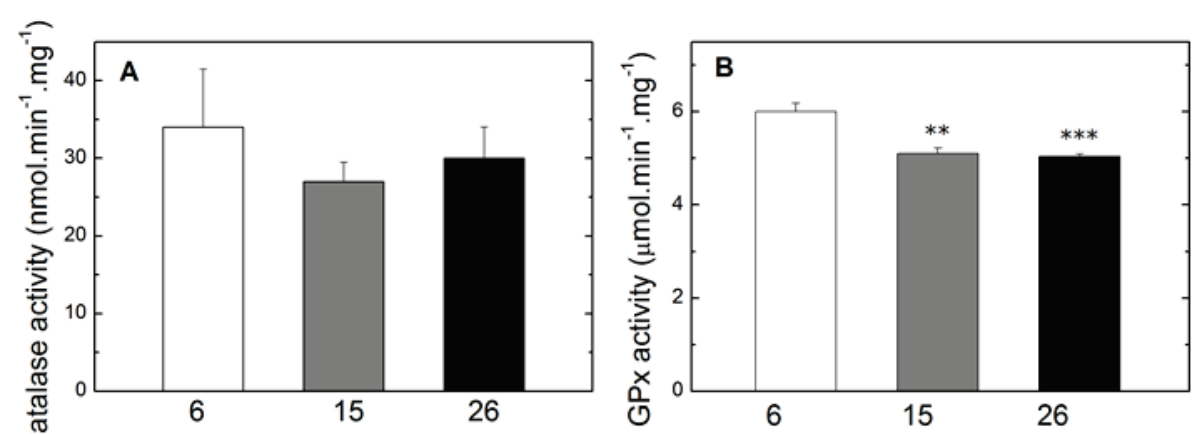

Fig. 3. Effect of aging on enzyme activities of catalase (A), glutathione peroxidase, GPx (B), glutathione reductase, GR (C), and thioredoxin reductase, $\operatorname{TrxR}$ (D). Values are given as mean \pm SEM of 5 experiments. ${ }^{*} \mathrm{p}<0.05 ; \quad * * \mathrm{p}<0.01 ; \quad * * * \mathrm{p}<0.001$; significantly different as compared to 6-month-old rats.

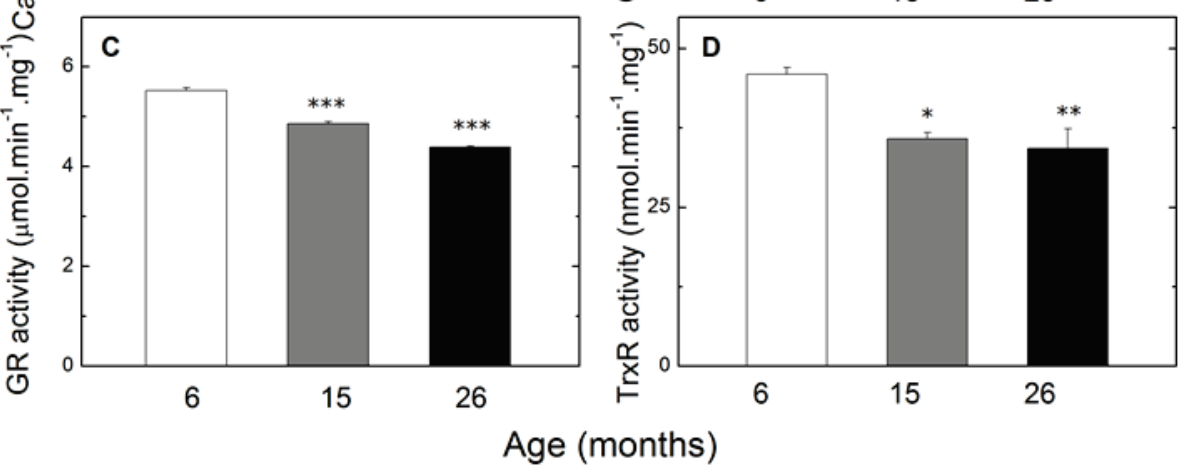

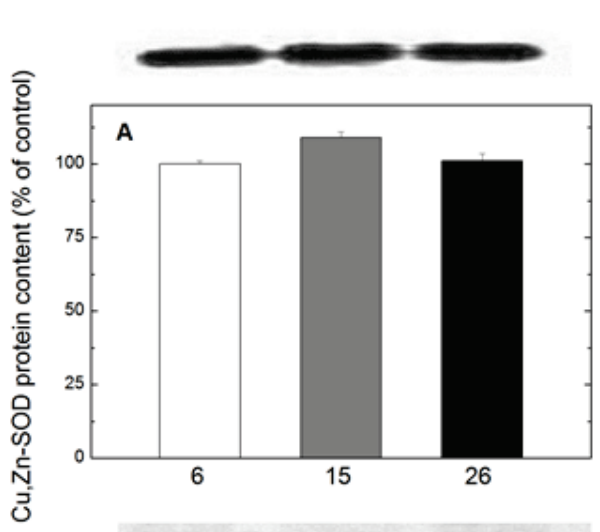

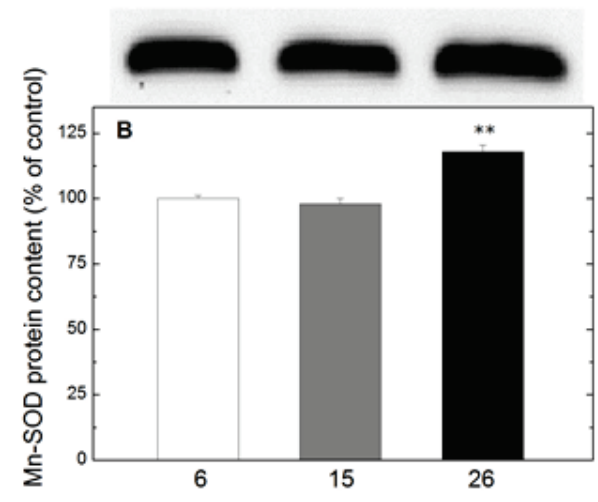

Fig. 4. Age-associated changes in protein expression. Densitometry analysis of immunoreactive band of $\mathrm{Cu}, \mathrm{Zn}$-superoxide dismutase, $\mathrm{Cu}, \mathrm{Zn}$ SOD (A), Mn-superoxide dismutase, Mn-SOD (B), and catalase (C). Representative immunoblots are depicted on top of the bar graphs. Values are given as means \pm SEM of 5 experiments. $* * p<0.01$; signifycantly different when compared to 6-month-old rats.

\section{Discussion}

To investigate the role of cellular redox status in cardiac aging we measured protein expression and activities of critical antioxidant enzymes and cellular redox systems in hearts of 6-, 15-, and 26-month-old rats. Our results support the hypothesis that aging is associated with alterations in cellular redox status and altered redoxregulation of cellular functions.

The present findings show that levels of GSH and total mercaptans decrease in 26- but not in 15-monthold rat hearts. Several studies using Wistar (Cocco et al. 2005, Parildar et al. 2008, Jacob et al. 2010) or Fischer 344 (Bejma et al. 2000, Suh et al. 2003) rats have also 


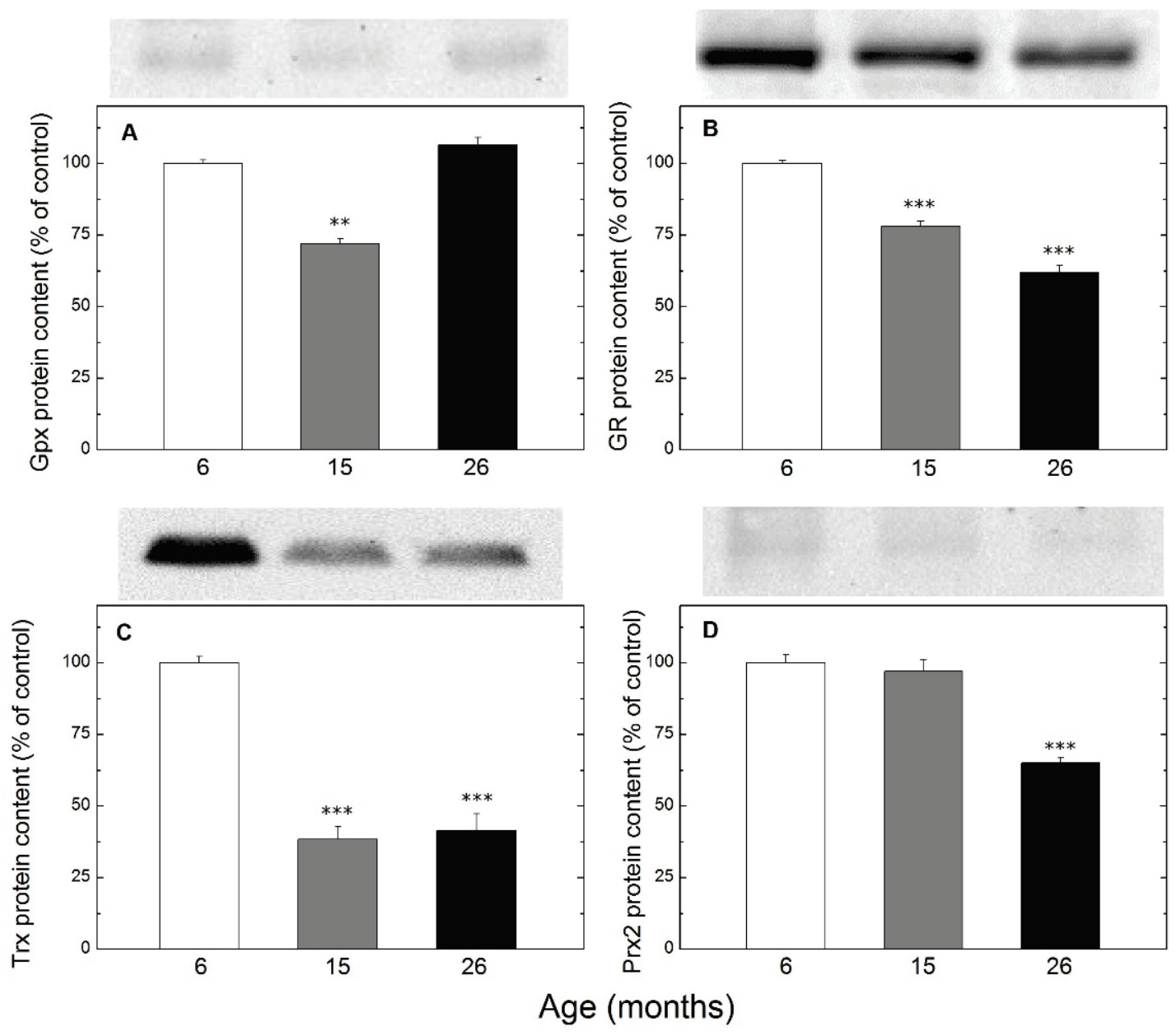

Fig. 5. Age-associated changes in protein expression. Densitometry analysis of immunoreactive band of glutathione peroxidase, GPx (A), glutathione reductase, GR (B), thioredoxin, $\operatorname{Trx}(\mathbf{C})$, and peroxiredoxin 2, $\operatorname{Prx} 2$ (D). Representative immunoblots are depicted on top of the bar graphs. Values are given as means \pm SEM of 5 experiments. $* * p<0.01 ; * * p<0.001$; significantly different when compared to 6-month-old rats

shown decreased GSH levels in senescent (24-28 month old) rats when compared to young adult (2-8 months old) controls, but group of old (14-18 month) rats was not investigated. In two studies using Sprague-Dawley (Ramesh et al. 2012) or Wistar (El-Sawalhi et al. 2013) rats reduced GSH level in 12-15-month-old rats was observed when compared to 2-3-month-old controls. A possible explanation for this discrepancy may be the difference in age of controls, rat strains, and assay method used. In this context it is interesting to note that human study on age-related changes in plasma antioxidants showed that total thiol level was unchanged between 53 and 99 years and decreased significantly only in centenarians (Mecocci et al. 2000). Our finding is consistent with this investigation and point out to the potential importance of altered cellular redox state in very old age.

Shift in the redox status can result from age-dependent increase in ROS production and/or decreased antioxidant defense system. Previous studies including ours have shown that aging is associated with increased generation of ROS in mitochondrial respiratory chain (Sohal et al. 1994, Bejma et al. 2000, Moghaddas et al. 2003, Petrosilo et al. 2009, Kuka et al. 2013). The decreased antioxidant contents and activities observed in the present study suggest that defense system also contributes to age-related oxidative stress and redox imbalance. The role of superoxide dismutases, catalase, and GPx is well characterized. $\mathrm{Cu}, \mathrm{Zn}-\mathrm{SOD}$ and $\mathrm{Mn}-\mathrm{SOD}$ dismutate superoxide radical to hydrogen peroxide, and catalase and GPx convert $\mathrm{H}_{2} \mathrm{O}_{2}$ to water. Previous studies have shown contradictory results with respect to effect of aging on their activities. Some studies on Fischer 344 (Meng et al. 2007, Picard et al. 2012) and SpragueDawley rats (Cebe et al. 2014) have shown that $\mathrm{Cu}, \mathrm{Zn}$ SOD activity decreases with aging while others using Wistar (Shinohara et al. 2000) or Fischer 344 (Tian et al. 1998) found no changes or changes only in senescent 
hearts, respectively. Similarly, Mn-SOD was found unaltered (Shinohara et al., Picard et al. 2012), decreased (Meng et al. 2007) or increased (Judge et al. 2005) during aging. In the present study, $\mathrm{Cu}, \mathrm{Zn}$-SOD activity slightly decreased only in the old heart and catalase activity/content displayed no age-related changes. In contrast, Mn-SOD activity decreased significantly with age despite unchanged (15-month-old) or slightly elevated (26-month-old) Mn-SOD protein level. These results indicate age-associated posttranslational modification and inactivation of an enzyme. Mn-SOD was found to be highly susceptible to oxidative/nitrative modification. In angiotensin II-infused rat kidney, tyrosine nitration of Mn-SOD accounted for about $20 \%$ of the total nitrated proteins and this resulted in $\sim 50 \%$ inhibition without change in protein content (Guo et al. 2003). Inhibition of Mn-SOD is of particular importance since it is the major antioxidant enzyme in mitochondria and its inhibition can result in an increased leak of superoxide radicals from respiratory chain. Attenuation of mitochondrial antioxidant capacity is further amplified by decreased activities/contents of GPx and GR. Our finding on GPx activity is consistent with previous studies in Wistar (Abete et al. 1999, Shinohara et al. 2000) and Sprague-Dawley (Ramesh et al. 2012) rats, but controversy remains, because several studies demonstrated unchanged (Tian et al. 1998, Bejma et al. 2000, Meng et al. 2007, Parildar et al. 2008, Picard et al. 2012) or increased (Judge et al., 2005) activity. Few studies examined GR function and have shown no change with aging (Abete et al. 1999, Judge et al. 2005). In 12-monthold rats GR activity was lowered when compared to young 2-month-old rats (Ramesh et al. 2012). Our findings indicate that both, activity and protein levels gradually decrease with age. GR catalyzes the reduction of oxidized glutathione to its active reduced form GSH and pronounced decline in GR activity in senescent rat hearts may contribute to diminished GSH level.

Thioredoxin system consisting of Trx, TrxR, and NADPH catalyzes the reduction of disulfides in proteins and plays a critical role not only in redox regulation but also in DNA synthesis, and protein repair (Lu and Holmgren 2014). Only relatively few studies have investigated this redox-regulatory system in cardiac aging. Using Sprague-Dawley rats Wang et al. (2013) showed that Trx level in aging rat heart was unaltered, but activity was decreased due to posttranslational nitrative modification. Bulvik et al. (2009) have found no age-related changes in Trx content when compared 24-25-month-old with 9-week-old rat hearts. Contrary to their findings we observed marked reduction in Trx levels in both old and senescent rat hearts. TrxR regenerates oxidized Trx to its active form with redox-active thiols in the catalytic center. Previous studies have shown that aging is associated with decreased level of mitochondrial TrxR2, whereas cytosolic TrxR1 is unaltered (Rohrbach et al. 2006, Wang et al. 2013). These and other (Bulvik et al. 2009) studies have also shown that total TrxR activity is reduced in senescent heart. Our results are in line with these findings and demonstrate that activity decreases markedly already in old rat heart. Additionally, these results suggest that the restoration of redox-active thiols is deteriorated with aging. Peroxiredoxins are redox-regulating proteins and antioxidants that reduce peroxides with electrons provided by Trx system (Lu and Holmgren 2014). In rat liver, aging was associated with marked increase in Prx3 isoform localized in mitochondria (Mussico et al. 2011). Peroxiredoxins are highly abundant in the heart, but their role in cardiovascular aging is not known. To the best of our knowledge, this is the first study in which expression of cytosolic Prx2 isoform during cardiovascular aging was investigated. We did not find any difference in Prx2 levels between old and adult control hearts; however, the level was significantly reduced in senescent rat hearts. Such findings are interesting considering that Prx2 is not only peroxidase but acts also as molecular chaperone and enhances resistance to cell death (Moon et al. 2005).

Taken together our results demonstrate that aging is associated with decreased activity and protein content of several antioxidant enzymes - free radical scavengers, and two major redox-regulatory systems GSH and Trx system. The primary finding of this study is that changes are more pronounced in senescent than in old rat hearts. Overall, the results support the view that aging is associated with changes in the redox state that could alter cellular signaling and regulation.

\section{Conflict of Interest}

There is no conflict of interest.

\section{Acknowledgements}

This work was partially supported by grant VEGA 1/0004/19 and project "Center of Excellence for Research on Personalized Therapy (CEVYPET)", code 26220120053, co-financed from EU sources and European Regional Development Fund. 


\section{References}

ABETE P, NAPOLI C, SANTORO G, FERRARA N, TRITTO I, CHIARIELLO M, RENGO F, AMBROSIO G: Age-related decrease in cardiac tolerance to oxidative stress. J Mol Cell Cardiol 31: 227-236, 1999.

BABUŠÍKOVÁ E, KAPLÁN P, LEHOTSKÝ J, JESEŇÁK M, DOBROTA D: Oxidative modification of rat cardiac mitochondrial membranes and myofibrils by hydroxyl radicals. Gen Physiol Biophys 23: 327-335, 2004.

BEJMA J, RAMIRES P, JI LL: Free radical generation and oxidative stress with ageing and exercise: differential effects in the myocardium and liver. Acta Physiol Scand 169: 343-351, 2000.

BULVIK B, GRINBERG L, ELIASHAR R, BERENSHTEIN E, CHEVION M: Iron, ferritin and proteins of the methionine-centered redox cycle in young and old rat hearts. Mech Ageing Dev 130: 139-144, 2009.

CEBE T, YANAR K, ATUKEREN P, OZAN, T, KURUÇ AI, KUNBAZ A, SITAR ME, MENGI M, AYDIN MH, EŞREFOĞLU M, AYDIN S, ÇAKATAY U: A comprehensive stdy of myocardial redox homeostasis in naturally and mimetically aged rats. AGE 36: 9728, 2014.

CEDIKOVA M, PITULE P, KRIPNEROVA M, MARKOVA M, KUNCOVA J: Multiple roles of mitochondria in aging process. Physiol Res 65 (Suppl 5): S519-S531, 2016.

CHOKSI KB, PAPACONSTANTINOU J: Age-related alterations in oxidatively damaged proteins of mouse heart mitochondrial electron transport chain complexes. Free Radic Biol Med 44: 1795-1805, 2008.

COCCO T, SGOBBO P, CLEMENTE M, LOPRIORE B, GRATTAGLIANO I, Di PAOLA M, VILLANI G: Tissuespecific changes of mitochondrial functions in aged rats: effect of a long-term dietary treatment with N-acetylcysteine. Free Radic Biol Med 38: 796-805, 2005.

EL-SAWALHI MM, DARWISH HA, MAUSOUF MN, SHAHEEN AA: Modulation of age-related changes in oxidative stress markers and energy status in the rat heart and hippocampus: a significant role for ozone therapy. Cell Biochem Funct 31: 518-525, 2013.

GONZALES R, AUCLAIR C, VOISIN E, GAUTERO H, DHERMY D, BOIVIN P: Superoxide dismutase, catalase, and glutathione peroxidase in red blood cells from patients with malignant diseases. Cancer Res 44 : 4137-4139, 1984.

GUO W, ADACHI T, MATSUI R, XU S, JIANG B, ZOU M-H, KIRBER M, LIEBERTHAL W, COHEN RA: Quantitative assessment of tyrosine nitration of manganese superoxide dismutase in angiotensin II-infused rat kidney. Am J Physiol Heart Circ Physiol 285: H1396-H1403, 2003.

JACOB MHVM, JANNER DR, ARAÚJO ASR, JAHN MP, KUCHARSKI LCR, MORAES TB, FILHO CSD, RIBERIO MFM, BELLÓ-KLEIN A: Redox imbalance influence in the myocardial Akt activation in aged rats treated with DHEA. Exp Gerontol 45: 957-963, 2010.

JUDGE S, JANG YM, SMITH A, HAGEN T, LEEUWENBURGH C: Age-associated increases in oxidative stress and antioxidant enzyme activities in cardiac interfibrillar mitochondria: implications for the mitochondrial theory of aging. FASEB J 19: 419-421, 2005.

KAPLAN P, JURKOVICOVA D, BABUSIKOVA E, HUDECOVA S, RACAY P, SIROVA M, LEHOTSKY J, DRGOVA A, DOBROTA D, KRIZANOVA O: Effect of aging on the expression of intracellular $\mathrm{Ca}^{2+}$ transport proteins in a rat heart. Mol Cell Biochem 301: 219-226, 2007.

KUKA S, TATARKOVA Z, RACAY P, LEHOTSKY J, DOBROTA D, KAPLAN P: Effect of aging on formation of reactive oxygen species by mitochondria of rat heart. Gen Phys Physiol 32: 415-420, 2013.

KUMARAN S, SUBATHRA M, BALU M, PANNEERSELVAM C: Supplementation of L-carnitine improves mitochondrial enzymes in heart and skeletal muscle of aged rats. Exp Aging Res 31: 55-67, 2005.

LENNON-EDWARDS S, SCHELLHARDT TA, KUCZMARSKI JM: Antioxidant defense is increased in aged hearts following omega-3 supplementation in the absence of changes in inflammation. Physiol Res 64: 433-438, 2015.

LU J, HOLMGREN A: The thioredoxin antioxidant system. Free Radic Biol Med 66: 75-87, 2014.

MAILLOUX RJ, JIN X, WILLMORE WG: Redox regulation of mitochondrial function with emphasis on cysteine oxidation reactions. Redox Biol 2: 123-139, 2014. 
MECOCCI P, POLIDORI MC, TROIANO L, CHERUBINI A, CECCHETTI R, PINI G, STRAATMAN M, MONTI D, STAHL W, SIES H, FRANCESCHI C, SENIN U: Plasma antioxidants and longevity: a study on healthy centenarians. Free Radic Biol Med 28: 1243-1248, 2000.

MENG Q, WONG YT, CHEN J, RUAN R: Age-related changes in mitochondrial function and antioxidative enzyme activity in Fischer 344 rats. Mech Ageing Dev 128: 286-292, 2007.

MOGHADDAS S, HOPPEL CL, LESNEFSKY EJ: Aging defect at the Qo site of complex III augments oxyradical production in rat heart interfibrillar mitochondria. Arch Biochem Biophys 414: 59-66, 2003.

MOON JC, HAH Y-S, KIM WY, JUNG BG, JANG HH, LEE JR, KIM SY, LEE YM, JEON MG, KIM CW, CHO MJ, LEE SY: Oxidative stress-dependent structural and functional switching of a human 2-Cys peroxiredoxin isotype II that enhances HeLa cell resistance to $\mathrm{H}_{2} \mathrm{O}_{2}$-induced cell death. J Biol Chem 31: 28775-28784, 2005.

MUSSICO C, CAPELLI V, PESCE V, TIMPERIO AM, CALVANI M, MOSCONI L, CANTATORE P, GADALETA $\mathrm{MN}$ : Rat liver mitochondrial proteome: changes associated with aging and acetyl-L-carnitine treatment. J Proteomics 74: 2536-2547, 2011.

PARILDAR H, DOĞRU-ABBASOĞLU S, MEHMETÇIK G, ÖZDEMIRLER G, KOÇAK-TOKER N, UYSAL M: Lipid peroxidation potential and antioxidants in the heart tissue of $\beta$-alanine- or taurine-treated old rats. $J$ Nutr Sci Vitaminol 54: 61-65, 2008.

PETROSILlO G, MATERA M, MORO N, RUGGIERO FM, PARADIES G: Mitochondrial complex I dysfunction in rat heart with aging: critical role of reactive oxygen species and cardiolipin. Free Radic Biol Med 46: 88-94, 2009.

PICARD M, WRIGHT KJ, RITCHIE D, THOMAS MM, HEPPLE RT: Mitochondrial function in permeabilized cardiomyocytes is largely preserved in the senescent rat myocardium. PloS One 7: e43003, 2012.

PRESTON CC, OBERLIN AS, HOLMUHAMEDOV EL, GUPTA A, SAGAR S, SYED RH, SIDDIQUI SA, RAGHAVAKAIMAL S, TERZIC A, JAHANGIR A: Aging-induced alterations in gene transcripts and functional activity of mitochondrial oxidative phosphorylation complexes in the heart. Mech Ageing Dev 129: 304-312, 2008.

RAMESH T, KIM S-W, SUNG J-H, HWANG S-Y, SOHN S-H, YOO S-K, KIM S-K: Effect of fermented Panax ginseng extract (GINST) on oxidative stress and antioxidant activities in major organs of aged rats. Exp Gerontol 47: 77-84, 2012.

ROHRBACH S, GRUENLER S, TESCHNER M, HOLTZ J: The thioredoxin system in aging muscle: key role of mitochondrial thioredoxin reductase in the protective effects of caloric restriction. Am J Physiol Regul Integr Comp Physiol 291: R927-R935, 2006.

SALMON A, RICHARDSON A, PÉREZ VI: Update on the oxidative stress theory of aging: does oxidative stress play a role in aging or healthy aging? Free Radic Biol Med 48: 642-655, 2010.

SHINOHARA R, MANO T, NAGASAKA A, HAYASHI R, UCHIMURA K, NAKANO I, WATANABE F, TSUGAWA T, MAKINO M, KAKIZAWA H, NAGATA M, IWASE K, ISHIZUKI Y, ITOH M: Lipid peroxidation levels in rat cardiac muscle are affected by age and thyroid status. J Endocrinol 164: 97-102, 2000.

SOHAL RS, KU H-H, AGARWAL S, FORSTER MJ, LAL H: Oxidative damage, mitochondrial oxidant generation and antioxidant defenses during aging and in response to food restriction in the mouse. Mech Ageing Dev 74: 121-133, 1994.

SOHAL RS, ORR WC: The redox stress hypothesis of aging. Free Radic Biol Med 52: 539-555, 2012.

SUH JH, HEATH SH, HAGEN TM: Two subpopulations of mitochondria in the aging rat heart display heterogenous levels of oxidative stress. Free Radic Biol Med 35: 1064-1072, 2003.

TATARKOVÁ Z, KUKA S, RAČAY P, LEHOTSKÝ J, DOBROTA D, MIŠTUNA D, KAPLÁN P: Effects of aging on activities of mitochondrial electron transport chain complexes and oxidative damage in rat heart. Physiol Res 60: 281-289, 2011.

TIAN L, CAI Q, WEI H: Alterations of antioxidant enzymes and oxidative damage to macromolecules in different organs of rats during aging. Free Radic Biol Med 24: 1477-1484, 1998. 
VAN REMMEN H, IKENO Y, HAMILTON M, PAHLAVANI M, WOLF N, THORPE SR, ALDERSON NL, BAYNES JW, EPSTEIN CJ, HUANG T-T, NELSON J, STRONG R, RICHARDSON A: Life-long reduction in MnSOD activity results in increased DNA damage and higher incidence of cancer but does not accelerate aging. Physiol Genomics 16: 39-37, 2003.

WANG K, ZHANG J, WANG X, LIU X, ZUO L, BAI K, SHANG J, MA L, LIU T, WANG L, WANG W, MA X, LIU

$\mathrm{H}$ : Thioredoxin reductase was nitrated in the aging heart after myocardial ischemia/reperfusion. Rejuvenation Res 16: 377-385, 2013.

WILHELM J, IVICA J, VESELSKA Z, UHLÍK J, VAJNER L: Changes in composition of fatty acids and lipofuscinlike pigments during development of the rat heart. Physiol Res 64: 643-651, 2015.

YEN PM: Physiological and molecular basis of thyroid hormone action. Physiol Rev 81: 1097-1142, 2001. 